Robbe Reykers

Thermal and Electrical Systems Research

Laboratory (THELES),

Cluster of Engineering Technology,

Mechanical Engineering Department,

KU Leuven,

Sint-Katelijne-Waver 2860, Belgium

e-mail: reykersrobbe@gmail.com

Raf Keersmaekers

Thermal and Electrical Systems Research Laboratory (THELES),

Cluster of Engineering Technology, Mechanical Engineering Department, KU Leuven,

Sint-Katelijne-Waver 2860, Belgium e-mail: Raf.keersmaekers@gmail.com

Nesrin Ozalp ${ }^{1}$

Fellow ASME

Thermal and Electrical Systems Research Laboratory (THELES),

Cluster of Engineering Technology, Mechanical Engineering Department, KU Leuven,

Sint-Katelijne-Waver 2860, Belgium e-mail: Nesrin.ozalp@kuleuven.be

\author{
Johan Collaert \\ GeoTherma, \\ Ambachtenstraat 14A, \\ Lubbeek 3210, Belgium \\ e-mail: j.collaert@geotherma.be
}

\section{Thermodynamic Analysis of a Novel Space Heating System Featuring Hot Gas Water Technology}

Low operating cost, comfort, sustainability, and environmental footprint are the key elements of robust space heating (SH) system. In quest for higher efficiencies, it is not always possible to meet all of these demands where environmental footprint often gets secondary attention. This paper presents a novel SH system which is capable of meeting all of the aforementioned elements while simultaneously proving SH and domestic hot water $(D H W)$. The system comprises a geothermal sourced heat pump (HP) featuring "hot gas water" (HGW) technology which delivers higher efficiency. This paper gives a thorough thermodynamic assessment of the system covering component based first and second law analysis and provides test results based on two case studies at a house (W10/W35) and a renovated building (W10/W45). The results show that a theoretical efficiency gain by $11.02 \%$ is achievable where the source temperature is $10^{\circ} \mathrm{C}$ and the water temperature for floor heating is $35^{\circ} \mathrm{C}$. For the same system, with the same source temperature but with a supply temperature of $45^{\circ} \mathrm{C}$ for $\mathrm{SH}$, an efficiency gain of $17.91 \%$ is achievable. From experimental testing of the system using the test stand at GeoTherma, $4.73 \%$ efficiency gain with water temperature of $35^{\circ} \mathrm{C}$ and $3.59 \%$ efficiency gain with water temperature of $45^{\circ} \mathrm{C}$ were obtained. Economic analysis results showed that savings of up to $10 \%$ on an annual basis is possible with HGW technology installed in an average family house, whereas it gets $4.36 \%$ for a small hotel with a payback time period of about 9 yrs. [DOI: 10.1115/1.4032770]

\section{Introduction}

$\mathrm{SH}$ is an integral part of building design for comfortable work and living environment. HPs have been widely used in residential and commercial sector by absorbing heat from a low-temperature medium and supplying it to a high-temperature medium for maintaining the heated space at high temperature. HPs are favorable in terms of energy conservation [1], and geothermal energy is an attractive source to utilize in HPs due to its sustainability as a source of clean energy [2]. The annual energy use of HP units making direct use of geothermal energy has grown 2.29 times at an annual rate of $18.0 \%$ since 2005 which ranks geothermal heat pumps (GHPs) as the largest energy use and installed capacity accounting for $68.3 \%$ and $47.2 \%$ of the worldwide capacity and use [3].

In general, HPs are used to generate heat for SH [4] or DHW [5]. Some HPs simultaneously provide SH and DHW as so-called HGW technology. Such simultaneous production is achieved by using the heat from compressed gas via an extra compact heat exchanger by the condensing side in series with the condenser, namely, the desuperheater. An example system was setup by Fernández-Seara et al. [6] where condenser delivers warm water for the SH and the storage tank, and the desuperheater heats it further so that it can be used for DHW. Coefficient of performances (COPs) for living conditions of $35^{\circ} \mathrm{C}$ and $45^{\circ} \mathrm{C}$ are 3.8 and 3 ,

\footnotetext{
Corresponding author.

Contributed by the Advanced Energy Systems Division of ASME for publication in the Journal of Energy Resources Technology. Manuscript received November 1, 2015; final manuscript received February 10, 2016; published online March 14, 2016. Assoc. Editor: S. O. Bade Shrestha.
}

respectively. Blanco et al. [7] experimentally studied a configuration where the water circuits are separated from each other. In that setup, an SH circuit for floor heating is heated through the condenser and desuperheater separately heats up water in a boiler for DHW. COP of that system is 4.08 .

There is an added value of producing SH and DHW simultaneously. However, this benefit has not yet been thoroughly investigated via a commercially proven test compared to a standard HP cycle that has to produce the same heat demand separately for SH and DHW. This paper fills up that gap by providing experimental and theoretical analysis and demonstrates comparison by running tests using an HP manufacturer Thermia's system featuring HGW technology which offers an efficiency enhancement of $10 \%$. Performance of this new technology is compared with two other setups, namely, a house (W10/W35) and a renovated building (W10/W45), where $\mathrm{W} 10 / \mathrm{W} 35$ demands $35^{\circ} \mathrm{C}$ for floor heating (water), and $\mathrm{W} 10 / \mathrm{W} 45$ demands $45^{\circ} \mathrm{C}$ for radiator heating (also with water). In both cases, heat is extracted from the Earth through groundwater at $10^{\circ} \mathrm{C}$.

\section{HP System With HGW Technology}

It is important to compare similar setups to the one used in this project which is an HP with HGW technology. An illustration of the setup is given in Fig. 1 along with the $P-h$ diagram of the process.

Configuration of the HP system with HGW technology has five major components as seen in Fig. 1: compressor, expansion valve, and three heat exchangers. The normal operating cycle consists of two heat exchangers, but this new technology has an extra 

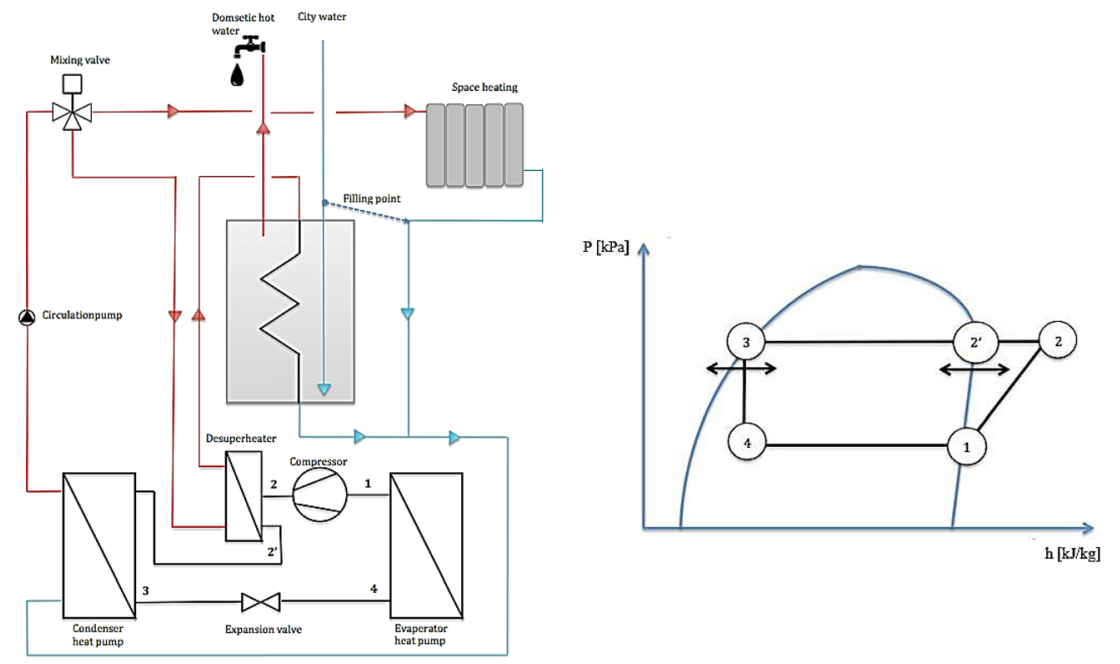

Fig. 1 Schematic of the simplified log $P-h$ diagram of the HP cycle with HGW technology

component, namely, the desuperheater which is in between points 2 and $2^{\prime}$ in Fig. 1. This is a small heat exchanger using the heat of superheated compressed gas to produce DHW, while the HP delivers SH simultaneously with higher COP. To clarify the cycles and thoroughly examine their performances, they are examined separately.

In $\mathrm{SH}$ circuit, heat capacity of the condenser is transferred to water and the heated water flows through a mixing valve. In a standard HP cycle, this is a three-way valve that switches between two modes: hot water for SH or DHW. Here, the mixing valve directs a small portion of the heated water flow to the desuperheater. The rest of the water proceeds to take care of the $\mathrm{SH}$ mostly via a floor heating system. There is a small part of the $\mathrm{SH}$ flow controlled by the mixing valve to the desuperheater in the DHW circuit. At this stage, the superheated compressed gas transfers its heat to the already heated water from the condenser, therefore, the heating process continues. Then, this hot water moves into a boiler tank, in which cold city water is warmed up through a spiral tube, so that it can be used for sanitary applications. This process is called tap water stratification, transporting heat quickly and efficiently and also distributing water in different layers at different temperatures in the boiler tank. The cooled water that comes out of the spiral tube, together with the water used for $\mathrm{SH}$, flows back to the condenser, where the process starts again.

The HP cycle can be presented by a logarithmic $P-h$ diagram where the amount of work is presented as a line segment. The course of the heat transfer process can be explained by referring to the $P-h$ diagram, in which the $y$-axis represents the pressure in logarithmic scale and the $x$-axis stands for the enthalpy.

The following assumptions have been made to explain this process:

- No pressure drop between condenser and desuperheater.

- Perfect isolation from the environment.

- In the evaporator, the entire refrigerant evaporates.

- Expansion is done via constant enthalpy (isenthalpic).

- Compression is done by keeping the entropy constant (isentropic).

Between states 2 and $2^{\prime}$, the superheated gas passes its heat to water in the compact heat exchanger, which is then used for DHW. Depending on the inlet variables, state of the refrigerant can be located in the vapor/liquid region or in the superheated region. In $P-h$ diagram, this is indicated by a small arrow below state $2^{\prime}$, pointing two directions as seen in Fig. 1. Ideally, state $2^{\prime}$ is in the vapor region, in this way all of the condensed heat are available in the condenser. After the gas phase refrigerant moves from the desuperheater to the condenser, the condensation heat is transferred to the water used for SH. Depending on the inlet variables, the state of the refrigerant can be located in the vapor/liquid region or in the liquid region between states $2^{\prime}$ and 3 . In the $P-h$ diagram, this is indicated by a small arrow below state 3 , pointing two directions as seen in Fig. 1.

We can now turn our attention to the HP system with HGW technology which is illustrated in Fig. 2. Schematic of the HP cycle with HGW technology shows that there are three water cycles marked in blue and one refrigerant cycle. This refrigerant cycle runs $\mathrm{R} 410 \mathrm{a}$ as the working fluid, which is frequently used in small and medium HPs. The states of the refrigerant cycle are marked by numbers from 1 to 4 , and they change through different system components such as the compressor, the desuperheater, the condenser, the expansion valve, and the evaporator. The working principle of these cycles has been explained earlier. Next, steps are to define each state with standard EN14511 [8] and to calculate the state properties.

\section{Two Case Studies in Comparison to HGW Performance}

Two actual operating conditions have been selected for comparison: a house (W10/W35) demanding $35^{\circ} \mathrm{C}$ for floor heating and a renovated building (W10/W45) demanding $45^{\circ} \mathrm{C}$ for radiator heating. In both situations, heat is extracted from the ground though groundwater at $10^{\circ} \mathrm{C}$. The ideal properties for each living conditions are assumed as follows:

\section{W10/W35:}

- evaporator temperature water cycle (inlet $=10^{\circ} \mathrm{C} /$ outlet $=7^{\circ} \mathrm{C}$ )

- evaporator temperature refrigerant cycle (inlet $=7^{\circ} \mathrm{C} /$ outlet $=10^{\circ} \mathrm{C}$ )

— inlet compressor $\rightarrow$ saturated vapor

- desuperheater temperature water cycle (inlet $=35^{\circ} \mathrm{C} /$ outlet $=55^{\circ} \mathrm{C}$ )

- desuperheater temperature refrigerant cycle (inlet $=55^{\circ} \mathrm{C} /$ outlet $=35^{\circ} \mathrm{C}$ )

- desuperheater outlet refrigerant cycle $\rightarrow$ saturated vapor

- condenser temperature water cycle (inlet $=30^{\circ} \mathrm{C} /$ outlet $=35^{\circ} \mathrm{C}$ )

- condenser temperature refrigerant cycle (inlet $=35^{\circ} \mathrm{C} /$ outlet $=30^{\circ} \mathrm{C}$ )

- condenser outlet refrigerant cycle $\rightarrow$ saturated liquid 


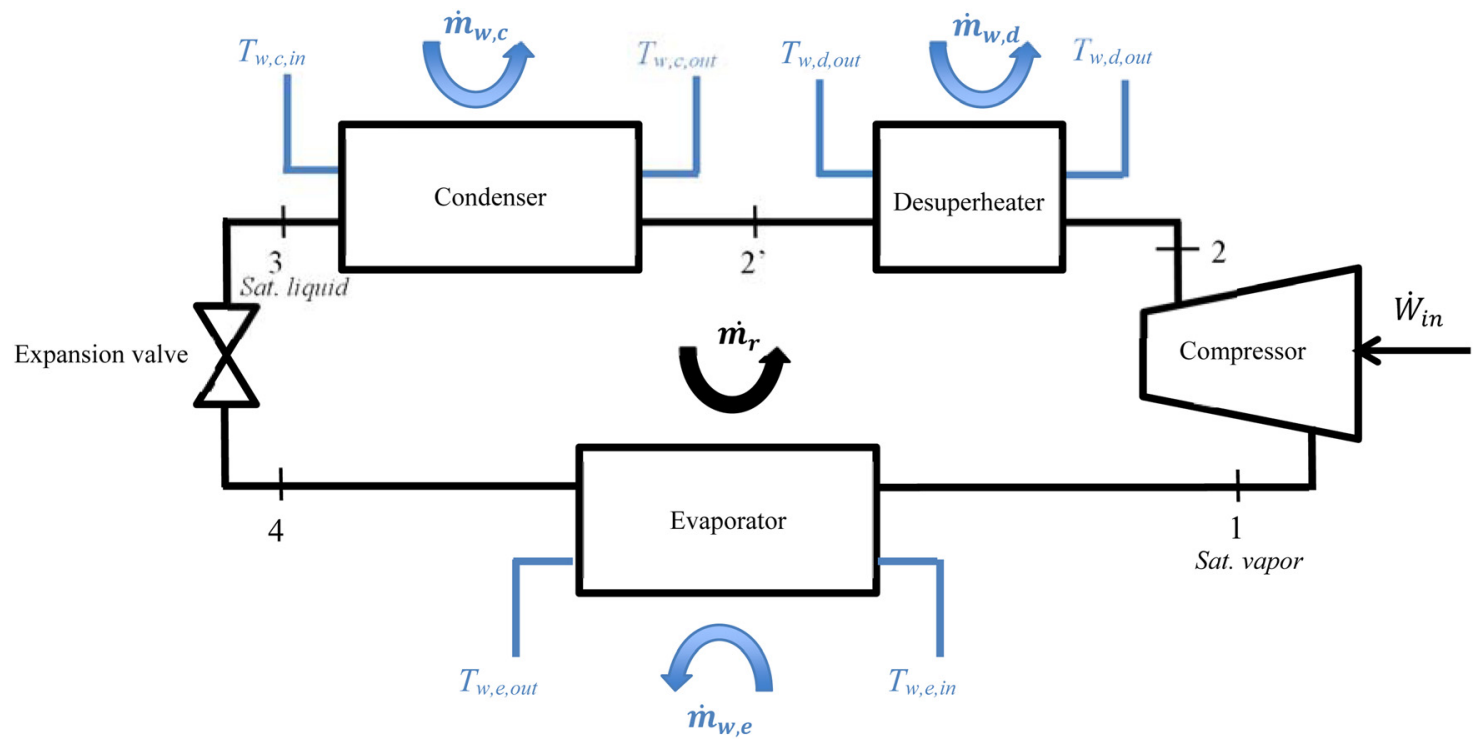

Fig. 2 Schematic of the HP system with HGW technology

W10/W45:

- evaporator temperature water cycle (inlet $=10^{\circ} \mathrm{C} /$ outlet $=7^{\circ} \mathrm{C}$ )

- evaporator temperature refrigerant cycle (inlet $=7^{\circ} \mathrm{C}$ / outlet $=10^{\circ} \mathrm{C}$ )

— inlet compressor $\rightarrow$ saturated vapor

- desuperheater temperature water cycle (inlet $=45^{\circ} \mathrm{C}$ / outlet $=55^{\circ} \mathrm{C}$ )

- desuperheater temperature refrigerant cycle (inlet $=55^{\circ} \mathrm{C} /$ outlet $=45^{\circ} \mathrm{C}$ )

- desuperheater outlet refrigerant cycle $\rightarrow$ saturated vapor

- condenser temperature water cycle (inlet $=40^{\circ} \mathrm{C}$ / outlet $=45^{\circ} \mathrm{C}$ )

- condenser temperature refrigerant cycle (inlet $=45^{\circ} \mathrm{C}$ / outlet $=40^{\circ} \mathrm{C}$ )

- condenser outlet refrigerant cycle $\rightarrow$ saturated liquid

These temperatures are target temperatures to maximize the heat exchange and they represent ideal cases.

\section{Thermodynamic Cycle Analysis of the HP System}

In order to evaluate the COP, a thermodynamic analysis based on the energy and mass balances is done. Figure 3 demonstrates the methodology of this analysis as per first and second laws of thermodynamics.

The following assumptions represent the ideal case and are made to simplify the calculations:

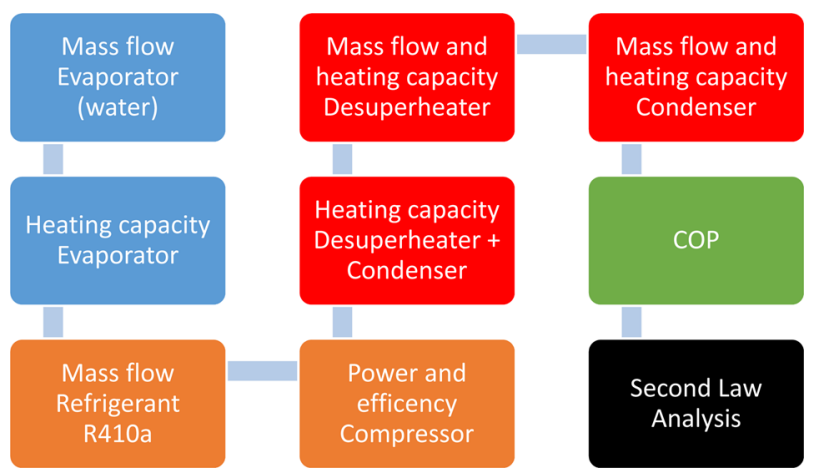

Fig. 3 Step-by-step calculation flow of the first and second law analysis

Journal of Energy Resources Technology
- Expansion valve process is isenthalpic.

- Compression process has the maximal isentropic efficiency.

- Condensation and evaporation process are isobaric.

- Refrigerant in states 1 and $2^{\prime}$ is saturated vapor and in state 3 it is saturated liquid.

\subsection{First Law Analysis}

4.1.1 Mass Flow of Water in the Evaporator, $\dot{m}_{w, e}$. The pump of the evaporator's water cycle has a fixed volumetric flow rate, in $\mathrm{m}^{3} / \mathrm{h}$, which is converted to mass flow rate in $\mathrm{kg} / \mathrm{s}$. This given value is the starting point of the thermodynamic analysis per conservation of mass.

4.1.2 Heating Capacity of the Evaporator. $\dot{Q}_{e}=\dot{Q}_{L}$ : The conservation of energy for the evaporator is given as

$$
\begin{gathered}
\dot{E}_{\text {in }}-\dot{E}_{\text {out }}=\Delta \dot{E}_{\text {system }} \\
\dot{m}_{w, e, \text { in }} \cdot h_{w, \text { e in }}+\dot{m}_{4} \cdot h_{4}=\dot{m}_{w, \text { e out }} \cdot h_{w, e, \text { out }}+\dot{m}_{1} \cdot h_{1}
\end{gathered}
$$

where

$$
\begin{gathered}
\dot{m}_{\mathrm{in}}-\dot{m}_{\mathrm{out}}=\Delta \dot{m}_{\mathrm{system}} \\
\dot{m}_{w, e, \text { in }}=\dot{m}_{w, e \text { out }}=\dot{m}_{w, e} \rightarrow \dot{m}_{4}=\dot{m}_{1}=\dot{m}_{r}
\end{gathered}
$$

Combining with the energy balance for the heat exchanger gives

$$
\dot{Q}_{e}=\dot{m}_{w, e}\left(h_{w, e, \text { in }}-h_{w, e, \text { out }}\right)
$$

4.1.3 Mass Flow of the R410a-Cycle, $\dot{m}_{r}$. An energy balance for the heat exchanger gives

$$
\dot{m}_{r}=\frac{\dot{m}_{w, e}\left(h_{w, e, \text { in }}-h_{w, e, \text { out }}\right)}{\left(h_{1}-h_{4}\right)}
$$

4.1.4 Total Heating Capacity, $\dot{Q}_{H}$. The heating capacity of the desuperheater and the condenser is

$$
\dot{Q}_{H}=\dot{m}_{r}\left(h_{2}-h_{3}\right)
$$

4.1.5 Power Consumption of the Compressor, $\dot{W}_{\text {comp }}$. Per conservation of energy 


$$
\dot{m}_{1} \cdot h_{1}+\dot{m}_{r} \cdot w_{\text {comp }}=\dot{m}_{2} \cdot h_{2}
$$

From conservation of mass

$$
\dot{m}_{1}=\dot{m}_{2}=\dot{m}_{r}
$$

Energy balance for the compressor gives

$$
h_{1}+w_{\text {comp }}=h_{2} \rightarrow w_{\text {comp }}=h_{2}-h_{1} \rightarrow \dot{W}_{\text {comp }}=\dot{m}_{r} \cdot w_{\text {comp }}
$$

To check the calculation, a comparison can be made whether $\dot{W}_{\text {comp }}=\dot{Q}_{H}-\dot{Q}_{L}$.

4.1.6 Compressor Efficiency, $\eta_{\text {comp }}$. Efficiency of the compressor is found from

$$
\eta_{\text {comp }}=\frac{h_{2 s}-h_{1}}{h_{2}-h_{1}}
$$

where $h_{2 s}$ stands for the enthalpy for a compressor with an isentropic efficiency of $100 \%$. Comparison with the ideal cycle shows that the most optimum efficiency is reached when HGW technology is being used.

4.1.7 Mass Flow of Water in Desuperheater Cycle, $\dot{m}_{w, d}$. Per conservation of energy

$$
\dot{m}_{w, d, \text { in }} \cdot h_{w, d, \text { in }}+m_{2} \cdot h_{2}=\dot{m}_{w, d, \text { out }} \cdot h_{w, d, \text { out }}+\dot{m}_{2^{\prime}} \cdot h_{2^{\prime}}
$$

where

$$
\dot{m}_{w, d, \text { in }}=\dot{m}_{w, d, \text { in }}=\dot{m}_{w, d} \rightarrow \dot{m}_{2}=\dot{m}_{2^{\prime}}=\dot{m}_{r}
$$

Energy balance on the heat exchanger gives

$$
\dot{m}_{w, d}=\frac{\dot{m}_{r}\left(h_{2}-h_{2^{\prime}}\right)}{\left(h_{w, d, \text { out }}-h_{w, d, \text { in }}\right)}
$$

4.1.8 Heating Capacity of the Desuperheater, $\dot{Q}_{d}$. Energy balance over the heat exchanger gives

$$
\dot{Q}_{d}=\dot{m}_{r}\left(h_{2}-h_{2^{\prime}}\right)
$$

4.1.9 Mass Flow of Water in Condenser Cycle, $\dot{m}_{w, c}$. ConserConservation of energy gives

$$
\dot{m}_{w, c, \text { in }} \cdot h_{w, c, \text { in }}+\dot{m}_{2^{\prime}} \cdot h_{2^{\prime}}=\dot{m}_{w, c, \text { out }} \cdot h_{w, c, \text { out }}+\dot{m}_{3} \cdot h_{3}
$$

where mass balance gives

$$
\dot{m}_{w, c, \text { in }}=\dot{m}_{w, c, \text { in }}=\dot{m}_{w, c} \rightarrow \dot{m}_{2^{\prime}}=\dot{m}_{3}=\dot{m}_{r}
$$

Per energy balance for the heat exchanger

$$
\dot{m}_{w, c}=\frac{\dot{m}_{r}\left(h_{2^{\prime}}-h_{3}\right)}{\left(h_{w, c, \text { out }}-h_{w, c, \text { in }}\right)}
$$

4.1.10 Heating Capacity of the Condenser, $\dot{Q}_{c}$. An energy balance on the heat exchanger gives

$$
\dot{Q}_{c}=\dot{m}_{r}\left(h_{2^{\prime}}-h_{3}\right)
$$

To check the calculation, we can refer to $\dot{Q}_{\text {tot }}=\dot{Q}_{H}=\dot{Q}_{c}$ $+\dot{Q}_{d}=6.44 \mathrm{~kW}+0.8195 \mathrm{~kW}=7.26 \mathrm{~kW}$.

4.1.11 COP, $C O P_{H P}$, and $C O P_{H P, \max }$. COP of the HP is calculated from

$$
\mathrm{COP}_{\mathrm{HP}}=\frac{\dot{Q}_{H}}{\dot{W}_{\text {comp }}} \text { and } \mathrm{COP}_{\mathrm{HP}, \max }=\frac{1}{\frac{1-\left(T_{L}\right)}{\left(T_{H}\right)}}
$$

4.2 Second Law Analysis. Second law analysis provides a comparison between different components per exergy. With the assumption of $293 \mathrm{~K}$ dead state temperature, formulas to perform second law analysis are as follows for each component.

Evaporator: Per entropy balance

$$
\begin{gathered}
\dot{S}_{\text {in }}-\dot{S}_{\text {out }}+\dot{S}_{\text {gen }}=\Delta \dot{S}_{\text {system }}=0 \\
\dot{m}_{w, e} \cdot s_{w, e, \text { in }}+\dot{m}_{r} \cdot s_{4}-\dot{m}_{w, e} \cdot s_{w, e, \text { out }}-\dot{m}_{r} \cdot s_{1}=-\dot{S}_{\text {gen }} \\
\dot{S}_{\text {gen }}=\dot{m}_{w, e} \cdot\left(s_{w, e, \text { out }} s_{w, e, \text { in }}\right)+\dot{m}_{r}\left(s_{1}-s_{4}\right) \\
\dot{X}_{\text {Dest }, e}=T_{0} \cdot \dot{S}_{\text {gen }}
\end{gathered}
$$

Compressor: From entropy balance

$$
\begin{gathered}
\dot{m}_{r} \cdot s_{2}-\dot{m}_{r} \cdot s_{1}=\dot{S}_{\text {gen }} \\
\dot{S}_{\text {gen }}=\dot{m}_{r}\left(s_{2}-s_{1}\right) \\
\dot{X}_{\text {Dest,comp }}=T_{0} \cdot \dot{S}_{\text {gen }}
\end{gathered}
$$

Desuperheater: Per entropy balance

$$
\begin{gathered}
\dot{m}_{w, d} \cdot s_{w, d, \text { in }}+\dot{m}_{r} \cdot s_{2}-\dot{m}_{w, d} \cdot s_{w, d, \text { out }}-\dot{m}_{r} \cdot s_{2^{\prime}}=-\dot{S}_{\text {gen }} \\
\dot{S}_{\text {gen }}=\dot{m}_{w, d} \cdot\left(s_{w, d, \text { out }}-s_{w, d, \text { in }}\right)+\dot{m}_{r} \cdot\left(s_{2^{\prime}}-s_{2}\right) \\
\dot{X}_{\text {Dest }, d}=T_{0} \cdot \dot{S}_{\text {gen }}
\end{gathered}
$$

Condenser: From entropy balance

$$
\begin{gathered}
\dot{m}_{w, c} \cdot s_{w, c, \text { in }}+\dot{m}_{r} \cdot s_{2^{\prime}}-\dot{m}_{w, c} \cdot s_{w, c, \text { out }}-\dot{m}_{r} \cdot s_{3}=-\dot{S}_{\text {gen }} \\
\dot{S}_{\text {gen }}=\dot{m}_{w, c}\left(s_{w, c, \text { out }}-s_{w, c, \text { in }}\right)+\dot{m}_{r} \cdot\left(s_{3}-s_{2^{\prime}}\right) \\
\dot{X}_{\text {Dest }, c}=T_{0} \cdot \dot{S}_{\text {gen }}
\end{gathered}
$$

Expansion valve: Per entropy balance

$$
\begin{gathered}
\dot{m}_{r} \cdot s_{3}-\dot{m}_{r} s_{4}=-\dot{S}_{\mathrm{gen}} \\
\dot{S}_{\mathrm{gen}}=\dot{m}_{r} \cdot\left(s_{4}-s_{3}\right) \\
\dot{X}_{\text {Dest,ev }}=T_{0} \cdot \dot{S}_{\mathrm{gen}}
\end{gathered}
$$

4.3 Results. The results of the first and second law analysis are compiled in Table 1 below for living conditions of $35^{\circ} \mathrm{C}$ and $45^{\circ} \mathrm{C}$ via HP cycle with and without HGW technology. The W10/ W55 regime represents the DHW production in a regular HP without HGW technology. This calculation is based on parameters of the both regimes with HGW. For these calculations, the temperature of the water coming out of the desuperheater is set at $55^{\circ} \mathrm{C}$. This water is used for DHW applications. As noted earlier, standard HP cycle does not have desuperheater which effectuates DHW while SH is simultaneously produced. Without the desuperheater, the condenser must handle the entire heat transfer operating on two separate regimes (W10/W35 or W10/W45 and W10/ W55) to deliver on the same demand as the HP featuring HGW 
Table 1 Summary of results for W10/W35 and W10/W45 with and without HGW technology

\begin{tabular}{|c|c|c|c|c|c|c|c|c|c|c|c|}
\hline Cycle & $\begin{array}{c}\dot{m}_{w, e} \\
(\mathrm{~kg} / \mathrm{s})\end{array}$ & $\begin{array}{c}\dot{Q}_{L} \\
(\mathrm{~kW})\end{array}$ & $\begin{array}{c}\dot{m}_{r} \\
(\mathrm{~kg} / \mathrm{s})\end{array}$ & $\underset{(\mathrm{kW})}{\dot{Q}_{h}}$ & $\begin{array}{c}\dot{W}_{\text {comp }} \\
(\mathrm{kW})\end{array}$ & $\begin{array}{c}\eta_{c} \\
(\%)\end{array}$ & $\begin{array}{c}\dot{m}_{w, d} \\
(\mathrm{~kg} / \mathrm{s})\end{array}$ & $\begin{array}{c}\dot{Q}_{D} \\
(\mathrm{~kW})\end{array}$ & $\begin{array}{c}\dot{m}_{w, c} \\
(\mathrm{~kg} / \mathrm{s})\end{array}$ & $\underset{(\mathrm{kW})}{\dot{Q}_{c}}$ & $\mathrm{COP}$ \\
\hline W10/W35 with HGW & 0.5 & 6.27 & 0.0372 & 7.26 & 0.993 & 68.24 & 0.0097 & 0.82 & 0.3051 & 6.44 & 7.31 \\
\hline W10/W35 without HGW & 0.5 & 6.27 & 0.0372 & 7.26 & 0.993 & 68.24 & - & - & 0.3459 & 7.26 & 7.31 \\
\hline W10/W55 without HGW & 0.5 & 6.27 & 0.0507 & 8.59 & 2.31 & 68.24 & - & - & 0.4069 & 8.59 & 3.70 \\
\hline W10/W45 with HGW & 0.5 & 6.27 & 0.0425 & 7.32 & 1.055 & 100 & 0.0215 & 0.91 & 0.3038 & 6.42 & 6.95 \\
\hline W10/W45 without HGW & 0.5 & 6.27 & 0.0425 & 7.32 & 1.055 & 100 & - & - & 0.3468 & 7.32 & 6.95 \\
\hline W10/W55 without HGW & 0.5 & 6.27 & 0.0507 & 9.67 & 3.402 & 100 & - & - & 0.4586 & 9.67 & 2.84 \\
\hline
\end{tabular}

Table 2 Calculation steps for total exergy destruction by HP system with HGW technology and a regular HP

\begin{tabular}{|c|c|c|c|c|c|c|c|}
\hline $\begin{array}{l}\text { Living } \\
\text { environment }\end{array}$ & $\begin{array}{c}\dot{X}_{\text {dest,total }} \text { SH } \\
(\mathrm{kW})\end{array}$ & $\begin{array}{l}t_{\mathrm{SH}} \\
(\mathrm{hr})\end{array}$ & $\begin{array}{c}\dot{X}_{\text {dest,total DHW }} \\
(\mathrm{kW})\end{array}$ & $\begin{array}{c}t_{\mathrm{DHW}} \\
(\mathrm{hr})\end{array}$ & $\begin{array}{c}X_{\text {dest,total }} \\
(\mathrm{kWh})\end{array}$ & $\begin{array}{c}\dot{X}_{\text {dest,HGW }} \\
(\mathrm{kW})\end{array}$ & $\begin{array}{l}X_{\text {dest,total HGW }} \\
(\mathrm{kWh})\end{array}$ \\
\hline W10/W35 & 0.8001 & 0.97 & 2.5003 & 0.03 & 0.8511 & 0.6988 & 0.6988 \\
\hline W10/W45 & 1.0463 & 0.79 & 3.8492 & 0.21 & 1.6349 & 3.0577 & 3.0577 \\
\hline
\end{tabular}

technology $\left(Q_{h}=Q_{c}\right.$ instead of $\left.Q_{h}=Q_{c}+Q_{d}\right)$. The W10/W55 regime represents the DHW production in a regular HP without HGW technology. This calculation is done twice, based on parameters of the both regimes with HGW.

Because of the constant use of the same temperature difference and the same mass flow on the water side of the evaporator, the heat capacity to exchange heat with the refrigerant cycle also remains constant at $6.27 \mathrm{~kW}$. It should be noted that higher the output temperature along the condensing side, lower the COP value becomes. This is due to the fact that the temperature difference between condenser and evaporator is greater, thus work consumption of compressor increases. It should also be noted that the heat transfer rate of the desuperheater increases when the output temperature is higher yielding more sanitary hot water production at higher temperature regimes. Ideally, the maximum COP when using HGW technology is equal to the COP when the system only produces SH. Despite the calculations are executed for ideal case, the compressor, the expansion valve, and the condenser are the components mostly responsible for increase in total exergy destruction.

Following calculations provide the total exergy destroyed when the HP systems with and without HGW technology operate for $1 \mathrm{hr}$ in living conditions of W10/W35 and W10/W45. Table 2 summarizes the calculation methodology for total exergy destruction in HP systems with and without HGW technology.

Because the SH is basically the same cycle as the HGW technology without the desuperheater, the exergy destroyed for each component in that cycle should not be very different. This statement is correct for the living environment of W10/W35. But looking at the exergy destroyed by the compressor, condenser, and the expansion valve for living environment of W10/W45, there is a large difference in between the values. This explains why the theoretical total exergy destroyed shows too much of a difference between HGW and SH. For that reason, the results for living environment of W10/W45 cannot be considered as accurate. However,

Table 3 COP and electrical input differences between the HGW technology and a regular HP for living conditions W10/W35 and W10/W45

\begin{tabular}{lccc}
\hline \hline W10/W35 & With HGW & Without HGW & Difference (\%) \\
\hline COP & 7.31 & 6.58 & 11.02 \\
$W_{\text {comp }}(\mathrm{kWh})$ & 0.993 & 1.103 & 11.02 \\
W10/W45 & With HGW & Without HGW & Difference (\%) \\
\hline COP & 6.95 & 5.88 & 17.91 \\
$W_{\text {comp }}(\mathrm{kWh})$ & 1.055 & 1.244 & 17.91 \\
\hline \hline
\end{tabular}

the results for living environment of W10/W35 can be used for further discussions.

\section{Economic Analysis}

This section demonstrates the economic benefit of an HP system with HGW technology in comparison to a regular HP system for per two living environment, namely, a house (W10/W35), and a renovated building (W10/W45).

5.1 Theoretical Profit Determination. The distribution shows how much percentage of the heating capacity is delivered to the water cycle by each component. Figure 4 demonstrates the distribution for both regimes.

For higher temperature regime of $45^{\circ} \mathrm{C}$, amount of heat available in compressed vapor gasses corresponds $12.4 \%$ of the total heat capacity which is $11.3 \%$ higher than that of the $35^{\circ} \mathrm{C}$ regime. The electrical consumption is determined for both HP systems for $1 \mathrm{hr}$ duration. For the HP working in HGW mode, the electrical consumption is calculated as follows:

$$
W_{t}=\frac{Q_{H}}{\mathrm{COP}}
$$

For the regular HP system working without the HGW technology, the calculation is split into two parts: $\mathrm{SH}$ with the condenser and DHW production with the desuperheater. Operation time for the SH part is calculated as follows:

$$
t=\frac{Q_{c}}{\dot{Q}_{H}}
$$

The electrical input for the $\mathrm{SH}$ portion

$$
W_{\mathrm{comp}, c}=\frac{\dot{Q}_{H}}{\mathrm{COP}} \cdot t
$$

The difference between the HGW technologies is that a portion of DHW is produced with a lower COP. The time that the valve takes for DHW production is

$$
t=\frac{Q_{d}}{\dot{Q}_{H}}
$$

The electrical input for the DHW portion is

$$
W_{\text {comp }, d}=\frac{\dot{Q}_{H}}{\mathrm{COP}} \cdot t
$$


The total electrical consumption to deliver the same heat demand via the HP with HGW technology is

$$
W_{t}=W_{\text {comp }, c}+W_{\text {comp }, d}
$$

The COP is calculated by taking the heating capacity produced and the total electrical consumption input as follows:

$$
\mathrm{COP}=\frac{Q_{H}}{W_{t}}
$$

Table 3 summarizes the results and shows the performance difference in terms of COP of the two systems.

It is obvious that the simultaneous production of $\mathrm{SH}$ and DHW by the HP system using HGW technology is more beneficial than the regular HP system producing the same amount of heating demand. For living conditions of W10/W35 delivering temperature of $35^{\circ} \mathrm{C}$, the profit is $11.02 \%$ which is more than what the manufacturer claims. However, it must be taken into account that these calculations are done for ideal conditions. In reality, the benefit is lower. The profit of the HGW technology versus a regular HP system is a lot higher for the W10/W45 than it is for the W10/ W35. This is because of selecting an isentropic efficiency of $100 \%$ which is not possible in actual case. Therefore, the living condition W10/W35 shows more realistic results after these calculations.

5.2 Case Studies. In this section, performance of an HP with HGW is compared to a regular HP for two cases: a house with a specific SH and DHW demand and a small hotel with larger DHW demand. On both cases, the living conditions W10/W35 and W10/ W45 are applied per aforementioned details of cycle specifics. Per data from GeoTherma, an average family house has a yearly $\mathrm{SH}$ demand of 20,000 kWh and a DHW demand of $4000 \mathrm{kWh}$. For the case of small hotel, DHW demand is equal to the SH demand of $20,000 \mathrm{kWh}$. In order to produce $20,000 \mathrm{kWh} \mathrm{SH}$ using an HP with HGW through the condenser, the following amount of heat is required:

$$
Q_{H, \mathrm{HGW}}=\frac{20,000 \mathrm{kWh}}{\% Q_{C}}
$$

whereas the electrical input using HGW technology is

$$
W_{\text {comp }, \mathrm{HGW}}=\frac{Q_{H, \mathrm{HGW}}}{\mathrm{COP}}
$$

The extra amount of energy that is produced for DHW on account of the desuperheater portion is

$$
Q_{d}=Q_{H, \mathrm{HGW}} \cdot \% Q_{d}
$$

It should be noted that there is $4000 \mathrm{kWh}$ demand for DHW. Therefore, $Q_{H, \mathrm{DHW}}=4000 \mathrm{kWh}-Q_{d}$ still needs to be produced for sanitary water use with a lower COP of the sanitary regime

$$
W_{\text {comp }, \mathrm{DHW}}=\frac{Q_{H, \mathrm{DHW}}}{\mathrm{COP}}
$$

The total electricity consumption to produce the required heat demand for SH and DHW is

$$
W_{t}=W_{\text {comp }, \mathrm{SH}}+W_{\text {comp }, \mathrm{DHW}}
$$

The COP is calculated per heating capacity produced and the total electricity consumption as follows:

$$
\mathrm{COP}=\frac{Q_{T}}{W_{t}}
$$

In order to produce $20,000 \mathrm{kWh}$ through the condenser to meet SH demand, the time it takes for the HP without HGW can be found as follows:

$$
t=\frac{Q_{H, \mathrm{SH}}}{\dot{Q}_{H}}
$$

whereas the electricity input to meet the $\mathrm{SH}$ demand can be calculated as follows:

$$
W_{\text {comp }, \mathrm{SH}}=\frac{\dot{Q}_{H}}{\mathrm{COP}} \cdot t
$$

In order to produce $4000 \mathrm{kWh}$ or $20,000 \mathrm{kWh}$ with the desuperheater to meet the DHW demand, the time it takes can be found from

$$
t=\frac{Q_{H, \mathrm{DHW}}}{\dot{Q}_{H}}
$$

whereas the electricity input for the DHW can be found from

$$
W_{\text {comp }, \mathrm{DHW}}=\frac{\dot{Q}_{H}}{\mathrm{COP}} \cdot t
$$

The total electricity consumption to produce the same amount of heat via the HP system with HGW technology is

$$
W_{t}=W_{\text {comp }, \mathrm{SH}}+W_{\text {comp,DHW }}
$$

The COP is calculated per the total heating capacity produced and total electricity consumption as follows:

$$
\mathrm{COP}=\frac{Q_{T}}{W_{t}}
$$

Table 4 summarizes the results and shows the difference (\%) between the two systems for the case study of a house.

Table 5 summarizes the results and shows the percentage difference between the two systems for the case study of a small hotel.

Comparison of the HGW technology use in a house versus in a small hotel shows that use of HGW technology instead of a standard HP for living condition of W10/W35 in an average family house goes up to approximately $10 \%$ on an annual basis, whereas it only gets $4.36 \%$ savings per year in a small hotel. Because the DHW demand in a small hotel is much higher, contribution of the HGW technology decreases because of the fact that more DHW is produced without HGW in the living condition of W10/W55 with lower COP. This makes the HGW technology less significant for usage in applications like small hotels where there is a high demand for DHW.

5.3 Payback Time. An HP system $(6 \mathrm{~kW})$ with HGW technology, which is the system used in the test stand, costs $€ 6828$ (excluding tax), while the price of a regular HP system is $€ 6432$

Table 4 Differences of the COP and electricity input between the HP with HGW technology and a regular HP in a house for living conditions of W10/35 and W10/W45

\begin{tabular}{lccc}
\hline \hline W10/W35 & With HGW & Without HGW & Difference (\%) \\
\hline COP & 6.90 & 6.29 & 9.77 \\
$W_{\text {comp }}(\mathrm{kWh})$ & 3476.53 & 3816.31 & 9.77 \\
W10/W45 & With HGW & Without HGW & Difference (\%) \\
\hline COP & 6.49 & 5.59 & 15.92 \\
$W_{\text {comp }}(\mathrm{kWh})$ & 3700.09 & 4289.05 & 15.92 \\
\hline \hline
\end{tabular}


Table 5 Differences of COP and electricity input between HP with HGW technology and a regular HP installed at a small hotel with living conditions W10/35 and W10/W45

\begin{tabular}{lrcc}
\hline \hline W10/W35 & With HGW & Without HGW & Difference (\%) \\
\hline COP & 5.13 & 4.91 & 4.36 \\
$W_{\text {comp }}(\mathrm{kWh})$ & 7800.85 & 8140.64 & 4.36 \\
W10/W45 & With HGW & Without HGW & Difference (\%) \\
\hline COP & 4.29 & 4.03 & 6.31 \\
$W_{\text {comp }}(\mathrm{kWh})$ & 9333.89 & 9922.85 & 6.31 \\
\hline \hline
\end{tabular}

Table 6 Yearly operation costs in a house based on electricity input per HGW technology and a regular HP for living condition of W10/W35

\begin{tabular}{lcc}
\hline \hline & With HGW & Without HGW \\
\hline$W_{\text {comp }}(\mathrm{kWh})$ & 3476.53 & 3816.31 \\
Cost/year & 730.07 & 801.43 \\
\hline
\end{tabular}

\section{Heat capacity distribution}

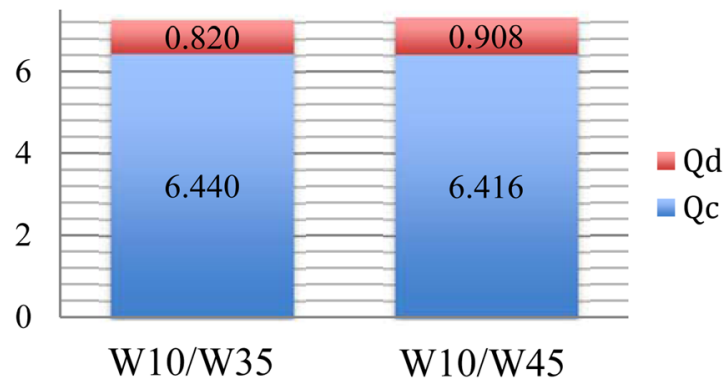

Fig. 4 Heat capacity and distribution of the desuperheater and condenser

(excluding tax). It is quite remarkable how $€ 396$ difference can give approximately $10 \%$ saving for an average family home. Taking the unit price of $1 \mathrm{kWh}$ as $€ 0.21$ [9], the yearly operation costs in a house would be as seen in Table 6 .
The time it takes to recover the investment made for an HP system with HGW technology versus a regular HP system for living condition of W10/W35 can be found as follows:

$$
\begin{aligned}
\text { Payback time HGW } & =\frac{\text { Extra cost HGW }}{\frac{\text { Savings }}{\text { year }}} \\
& =\frac{€ 396}{801.43 \frac{€}{\text { year }}-730.07 \frac{€}{\text { year }}}=5.55 \text { years }
\end{aligned}
$$

\section{Experimental Setup and Measurement Procedure}

This section is to check the theoretical calculations by running tests and taking measurements at Geotherma setup consisting of an HP system with HGW technology called Diplomat Optimum G3-6 kW. The test setup is subject to realistic conditions so that the contribution of HGW technology can be examined like it works in real llife.

6.1 Experimental Setup. Figure 5 demonstrates the principle operating scheme of the test setup with the measuring devices. The connections of the devices are drawn as a dotted line.

The main components of the test setup consist of a compressor, desuperheater, condenser, expansion valve, and evaporator. The desuperheater delivers heat for DHW and the condenser does the same for SH simultaneously. The cycle runs R410 as refrigerant and is a water/water HP.

Normally, the source tank is a cluster of heat exchanger pipes extracting heat from the Earth's surface. To represent that heat source in this test setup, the source tank and the output tank are added. In source tank, the evaporator extracts water that is kept constant at approximately $10^{\circ} \mathrm{C}$ by using an aquastat. The second tank is the output tank of the HP system, which represents the SH system. The water in this tank is heated by the condenser and it is directly used for SH. When the temperature of the source tank drops, the output tank provides the necessary heat so that the source tank maintains stable temperature. The temperature difference is set at $5^{\circ} \mathrm{C}$.

Aquastat is a sensor device to keep water temperature at the top of the source tank constantly at $10^{\circ} \mathrm{C}$. When the temperature decreases below $10^{\circ} \mathrm{C}$, the aquastat sends a signal to the pump

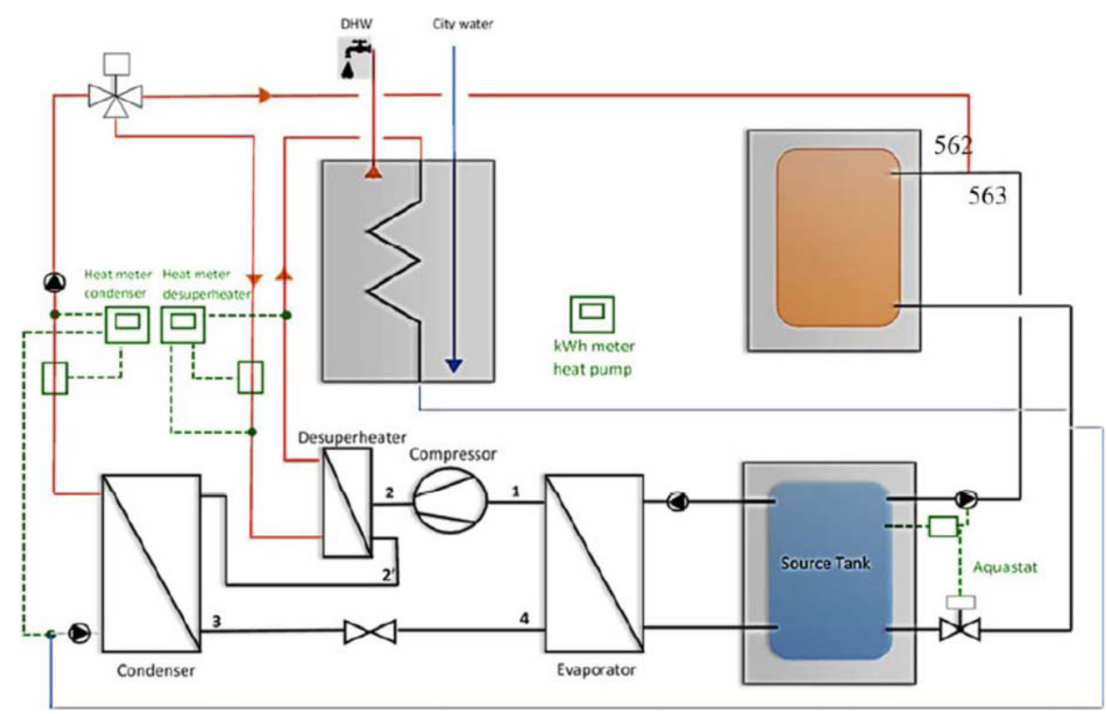

Fig. 5 Principle scheme of the test setup consists of an HP system with HGW technology 
and the valve, which are connected to the output tank. The warm water in the output tank then flow to the source tank to heat it up, while cold water is drained from the source tank to the output tank. That way, the water in source tank remains at constant temperature.

Heat-meter kits are heat sensors to measure water flow rate as well as the inlet and outlet temperature of the condenser and evaporator. These parameters can be read off the heat-meter display. Next to the actual heat transfer rate, the display also shows the heat transfer rate accumulated. Therefore, the measured parameters in this setup are: $\dot{V}, T_{w \text {,in }}, T_{w, \text { out }}, Q$, and $\dot{Q}$, whereas the kilowatt hour-meter is used to measure the electrical energy consumption of the HP $W_{\text {elec,hp. With thermocouples, the tempera- }}$ tures of the HP system cycle are manually measured as $T 1, T 2$, $T 2^{\prime}, T 3$, and $T 4$.

In addition to manual measurements, the HP system has built-in measuring components. For example, on the display of the HP system, inlet and outlet temperature of the water in the condenser and the evaporator can be observed as $T_{w, c, \text { in }}, T_{w, c, \text { out }}, T_{w, e, \text { in }}$, and $T_{w, e \text {,out }}$. These readings are used to double-check manual measurements. As for the water temperatures at the bottom and at the top of the DHW boiler, these temperatures can be read from the display as follows: $T_{\text {boiler,up }}, T_{\text {boiler,low, }}$ and $T_{\text {boiler }}$.

It should be noted that the HGW technology has required conditions concerning the temperature. The HGW temperature sensor is placed at the water outlet of the desuperheater to check this requirement. Between this temperature and the lower sensor temperature of the boiler tank, there has to be a difference of $25^{\circ} \mathrm{C}$. It is setup this way to make sure that the water at the top of the boiler tank does not cool down when heated water enters the boiler tank. The HGW technology starts heating up the water in case of heat demand only when this difference is accomplished.

6.2 Experimental Procedure. The measurements were taken at two living conditions stated in the theoretical analysis as W10/ W35 and W10/W45 per several time intervals. For both living conditions, the following were tested to observe the reaction of the HP system:

- Stationary installation: In this test, the HP was shut down or did not work for a while, meaning that the boiler of the DHW was completely cooled down. It is the fact that the boiler first needs to be warmed up to produce SH for the comfort of the users. As a reaction to this situation, the HP only produced DHW in order to heat the boiler as quickly as possible. As an example, Table 7 shows the measurement results for this test where the HP system is only producing DHW as marked in red.

- SH: The HP started producing heat for SH only when the boiler tank was warmed up.

- Shower and bath: For a realistic test and the use of HGW technology, DHW consumption is necessary. For example,

Table 7 Measurement results when the HP is only producing DHW

\begin{tabular}{|c|c|c|c|c|c|c|}
\hline Measuring & $\mathrm{Td} 1$ & $\mathrm{Td} 2$ & $\mathrm{Td} 3$ & $\mathrm{Td} 4$ & Td5 & Td6 \\
\hline Point of time & $11: 37: 00$ & $11: 44: 00$ & 11:53:00 & $12: 02: 00$ & $12: 10: 00$ & $12: 17: 00$ \\
\hline$\Delta t(\min )$ & - & 7 & 7 & 9 & 8 & 7 \\
\hline$T 1\left({ }^{\circ} \mathrm{C}\right)$ & 14.4 & 13.2 & 12.2 & 15.3 & 13.1 & - \\
\hline$T 2\left({ }^{\circ} \mathrm{C}\right)$ & 66.4 & 64.4 & 75.9 & 74.2 & 76.5 & - \\
\hline$T 2^{\prime}\left({ }^{\circ} \mathrm{C}\right)$ & 37.5 & 41.3 & 43.9 & 45.5 & 47.1 & - \\
\hline$T 3\left({ }^{\circ} \mathrm{C}\right)$ & 23.9 & 27.0 & 30.6 & 35.6 & 41.2 & - \\
\hline$T 4\left({ }^{\circ} \mathrm{C}\right)$ & 10.4 & 11.9 & 11.1 & 12.9 & 16.5 & - \\
\hline$T_{w, \text { evap,in }}$ (brine naar) $\left({ }^{\circ} \mathrm{C}\right)$ & 13.0 & 11.0 & 10.0 & 9.0 & 12.0 & - \\
\hline$T_{w, \text { evap,out }}($ brine van $)\left({ }^{\circ} \mathrm{C}\right)$ & 9.0 & 8.0 & 7.0 & 6.0 & 9.0 & - \\
\hline$Q_{e}(\mathrm{~kW})$ & - & 6.10 & 5.20 & 3.25 & 3.02 & - \\
\hline$M_{w, \text { evap }}(\mathrm{kg} / \mathrm{s})$ & - & 0.484 & 0.412 & 0.258 & 0.240 & - \\
\hline$T_{w, \text { desup,in }}(2)(\mathrm{C})$ & 43.0 & 45.0 & 44.0 & 46.0 & 47.0 & - \\
\hline$T_{w, \text { desup,out }}(1)\left({ }^{\circ} \mathrm{C}\right)$ & 45.0 & 48.0 & 48.0 & 48.0 & 49.0 & - \\
\hline$V_{w, \text { desup }}\left(\mathrm{m}^{3} / \mathrm{hr}\right)$ & 0.10 & 0.35 & 0.36 & 0.41 & 0.72 & - \\
\hline$m_{w, \text { desup }}(\mathrm{kg} / \mathrm{s})$ & 0.03 & 0.10 & 0.10 & 0.11 & 0.20 & - \\
\hline$Q_{d}(\mathrm{~kW})$ & 0.13 & 1.45 & 1.43 & 1.35 & 1.43 & - \\
\hline Heat meter $Q_{\text {desup }}(\mathrm{kWh})$ & 0.00 & 0.1 & 0.23 & 0.43 & 0.65 & 0.73 \\
\hline$Q_{\text {desup }}(\mathrm{kWh})$ & - & 0.10 & 0.13 & 0.20 & 0.22 & 0.08 \\
\hline$T_{w, \text { cond,in }}(2)\left({ }^{\circ} \mathrm{C}\right)$ & 24.0 & 26.0 & 29.0 & 34.0 & 40.0 & - \\
\hline$T_{w, \text { cond,in }}$ (display, check) $\left({ }^{\circ} \mathrm{C}\right)$ & 24.0 & 27.0 & 30.0 & 35.0 & 42.0 & - \\
\hline$T_{w, \text { cond,out }}(1)\left({ }^{\circ} \mathrm{C}\right)$ & 36.0 & 44.0 & 44.0 & 44.0 & 45.0 & - \\
\hline$T_{w, \text { cond,out }}\left(\right.$ display, check) $\left({ }^{\circ} \mathrm{C}\right)$ & 44.0 & 43.0 & 44.0 & 45.0 & 47.0 & - \\
\hline$V_{w, \text { cond }}\left(\mathrm{m}^{3} / \mathrm{h}\right)$ & 0.13 & 0.34 & 0.38 & 0.44 & 0.76 & - \\
\hline$m_{w, \text { cond }}(\mathrm{kg} / \mathrm{s})$ & 0.036 & 0.094 & 0.106 & 0.122 & 0.211 & - \\
\hline$Q_{c}(\mathrm{~kW})$ & 1.00 & 6.70 & 6.30 & 4.85 & 4.45 & - \\
\hline Heat meter $Q_{\text {cond }}(\mathrm{kWh})$ & 0.00 & 0.30 & 1.07 & 1.87 & 2.52 & 3.00 \\
\hline$Q_{\text {cond }}(\mathrm{kWh})$ & - & 0.30 & 0.77 & 0.80 & 0.65 & 0.48 \\
\hline KWh m & 56.43 & 56.62 & 56.85 & 57.12 & 57.38 & 57.6 \\
\hline$W_{\text {elec,hp }}(\mathrm{kWh})$ & - & 0.19 & 0.23 & 0.27 & 0.26 & 0.22 \\
\hline$W_{\text {equip }}(\mathrm{kWh})(0.162 \mathrm{~kW})$ & - & 0.0189 & 0.0189 & 0.0243 & 0.0216 & 0.0189 \\
\hline$W_{\text {comp }}(\mathrm{kWh})$ & - & 0.171 & 0.211 & 0.246 & 0.238 & 0.201 \\
\hline$W_{e}(\mathrm{~kW})$ & - & 2.053 & 2.533 & 2.948 & 2.861 & 2.413 \\
\hline$T_{\text {citywater }}\left({ }^{\circ} \mathrm{C}\right)$ & 17.0 & 17.0 & 17.0 & 17.0 & 17.0 & 17.0 \\
\hline$T_{\text {boiler,low }}\left({ }^{\circ} \mathrm{C}\right)$ & 22.0 & 23.0 & 28.0 & 33.0 & 38.0 & 41.0 \\
\hline$T_{\text {boiler,up }}\left({ }^{\circ} \mathrm{C}\right)$ & 25.0 & 31.0 & 36.0 & 41.0 & 45.0 & 47.0 \\
\hline$T_{\text {boiler, weight }}\left({ }^{\circ} \mathrm{C}\right)$ & 23.0 & 25.0 & 30.0 & 35.0 & 40.0 & 44.0 \\
\hline$V_{\mathrm{dhw}}\left({ }^{\circ} \mathrm{C}\right)$ & - & - & - & - & - & - \\
\hline$T_{\mathrm{dhw}}\left({ }^{\circ} \mathrm{C}\right)$ & - & - & - & - & - & - \\
\hline \multicolumn{7}{|l|}{ Space heating } \\
\hline Domestic hot water & & & & & & \\
\hline
\end{tabular}

Domestic hot wate

HGW

Comments

START boiler warm-up

Boiler $25^{\circ} \mathrm{C}$

Boiler $30^{\circ} \mathrm{C}$

Boiler $35^{\circ} \mathrm{C}$

Boiler $40^{\circ} \mathrm{C}$

STOP boiler warm up 
in an average family house, a shower takes up about 501 of water, and a bath would use about 1001 of water.

6.3 Data Reduction. The COP of the HP as well as the heat transfer rates and mass flows are calculated from the measured data

$$
\mathrm{COP}=Q_{H} / W_{t}
$$

The equipment that was used for other purposes than compressing vapor refrigerant was subtracted from the total electricity consumption of the HP system. Therefore, the total electricity consumption of the compressor is calculated by summing up the various power consumption values measured at different times

$$
W_{t}=\Sigma W_{\text {comp }}
$$

Referring to the theoretical calculations, it is known that the mass flow of the water cycle through the desuperheater at HGW mode is low. In fact, it is so low that it does not get noticed in system measurement component. Because the water flow rate is often too low to measure, it causes an inaccurate estimation for the heating capacity. However, the heat transfer rate of the desuperheater can be calculated referring to the heat transfer rate of the condenser in HGW conditions subtracted from the total heat transfer rate when the $\mathrm{HP}$ is only producing $\mathrm{SH}$

$$
\dot{Q}_{d}=\dot{Q}_{H}-\dot{Q}_{C}
$$

where the heat transfer rate of the evaporator is

$$
\dot{Q}_{e}=\dot{Q}_{c}-\dot{W}_{\text {comp }}
$$

Added with $Q_{d}$ in case of HGW mode, mass flows rates of three heat exchangers are calculated as follows:

$$
\begin{gathered}
\dot{m}_{w, e}=\frac{\dot{Q}_{e}}{c_{p, w} \cdot\left(T_{w, e, \text { in }}-T_{w, e, \text { ut }}\right)} \\
\dot{m}_{w, d}=\frac{\dot{V}_{w, d} \cdot \rho}{3600} \\
\dot{m}_{w, c}=\frac{\dot{V}_{w, c} \cdot \rho}{3600}
\end{gathered}
$$

\section{Results and Discussion}

Actual operating COPs are compared to the HP system with and without HGW technology and the theoretical values found per thermodynamic analysis.

7.1 COP. Table 8 summarizes the COPs of HGW technology system producing $\mathrm{SH}$ and DHW.

Table 8 shows that HGW technology has the best efficiency for living condition $\mathrm{W} 10 / \mathrm{W} 35$. COP value mentioned in the data sheet of the HP Diplomat Optimum G3-6 kW is 4.2 and has a heat capacity of $5.8 \mathrm{~kW}$. As this data sheet is for a living situation of B0/W35 which is for Brine instead of water and at a higher

Table 8 Comparison of actual operating COPs for living conditions of W10/W35 and W10/W45

\begin{tabular}{lccc}
\hline \hline & $\mathrm{COP}_{\mathrm{HGW}}$ & $\mathrm{COP}_{\mathrm{SH}}$ & $\mathrm{COP}_{\mathrm{DHW}}$ \\
\hline $\mathrm{W} 10 / \mathrm{W} 35$ & 4.86 & 4.69 & 3.39 \\
$\mathrm{~W} 10 / \mathrm{W} 45$ & 3.89 & 3.95 & 3.37 \\
\hline \hline
\end{tabular}

temperature difference between source and output, it can be concluded that the COP in Table 8 for living condition W10/W35 is higher. The difference in between the $\mathrm{COP}_{\mathrm{HGW}}$ and $\mathrm{COP}_{\mathrm{SH}}$ for living condition of W10/W45 is less noticeable. This shows the accuracy of the analysis as they are supposed to be equal because the heat demand to maintain $55^{\circ} \mathrm{C}$ is the same. Therefore, the $\mathrm{COP}_{\mathrm{DHW}}$ values should be equal for both conditions, which is the case.

7.2 Estimation of the Practical Profit. Table 9 summarizes the distribution of the heat transfer through the desuperheater and condenser for both living conditions.

It is remarkable that the heat transfer of the desuperheater is about seven times higher for W10/W45. Referring to the theoretical analysis, the heat capacity of the desuperheater is much lower. As a consequence, less DHW is being produced simultaneously and the efficiency decreases. The actual benefit was calculated for an operating time of $1 \mathrm{hr}$ and it is summarized in Table 10 by comparison to the values found from the theoretical estimation of the profit.

From these calculations, it is clear that the actual benefit is not as high as the theoretical profit. For the living condition W10/ W35, there is an actual profit of $4.73 \%$ versus a theoretical benefit of $11.02 \%$. As for the living condition of W10/W45, the actual profit is $3.59 \%$ whereas the theoretical profit is $17.9 \%$. Per discussion made according to the thermodynamic analysis, the isentropic efficiency of the living condition W10/W45 was assumed $100 \%$. The results in the table show that this is not possible under real conditions and highlights the importance of isentropic efficiency.

It should be noted that although $10 \%$ profit is not achieved in reality, there is still some profit made. For example, there is $4.73 \%$ in living condition of W10/W35 and $3.59 \%$ for living condition of W10/W45. Not achieving $10 \%$ profit might be caused by a possible deviation from the results due to an unstable source, some measurement errors, and poor insulation.

For the same living conditions, the realistic COP values for HP systems with and without HGW technology change less in reality than the theoretical values do. Because the actual COPs are lower, it is obvious that the electrical consumption is proportionally higher. It should be noted that per comfort choice of the end user, the HP system will not always operate in HGW mode. As it can

Table 9 Heat capacity and distribution of the desuperheater and condenser for living conditions of W10/W35 and W10/W45

\begin{tabular}{lccc}
\hline \hline & $\dot{Q}_{\text {desup }}(\mathrm{kW})$ & $\dot{Q}_{\text {cond }}(\mathrm{kW})$ & $\dot{Q}_{h}(\mathrm{~kW})$ \\
\hline W10/W35 with HGW & 0.20 & 6.23 & 6.43 \\
& $3.11 \%$ & $96.89 \%$ & $100 \%$ \\
W10/W45 with HGW & 1.41 & 5.23 & 6.68 \\
& $21.24 \%$ & $78.76 \%$ & $100 \%$ \\
\hline \hline
\end{tabular}

Table 10 Actual versus theoretical benefit of HP system with HGW technology against regular HP system

\begin{tabular}{lccc}
\hline \hline W10/W35 & With HGW & Without HGW & Difference (\%) \\
\hline COP & 4.86 & 4.64 & 4.73 \\
$W_{\text {comp }}(\mathrm{kWh})$ & 1.322 & 1.385 & 4.73 \\
COP $_{\text {th }}$ & 7.31 & 6.6 & 11.02 \\
$W_{\text {comp,th }}(\mathrm{kWh})$ & 0.993 & 1.103 & 11.02 \\
W10/W45 & With HGW & Without HGW & Difference (\%) \\
\hline $\mathrm{COP}$ & 3.89 & 3.81 & 3.59 \\
$W_{\text {comp }}(\mathrm{kWh})$ & 1.705 & 1.740 & 3.59 \\
$\mathrm{COP}_{\text {th }}$ & 6.943 & 5.88 & 17.9 \\
$W_{\text {comp,th }}(\mathrm{kWh})$ & 1.055 & 1.240 & 17.9 \\
\hline \hline
\end{tabular}


be seen in living condition W10/W35, for example, DHW demand for taking a shower, etc., the HP system will switch quickly from HGW technology to heat up the water in the boiler with a better COP. This is mainly because the water temperature for SH is considerably lower than the required water temperature for DHW. However, this occurs less rapidly when using HGW technology for the living condition of W10/W45.

\subsection{Case Study: House and Small Hotel}

7.3.1 House Case. It is obvious that the annual actual profit of the HGW technology would be lower than the theoretical profit in ideal conditions for an average family house. For the living condition of $\mathrm{W} 10 / \mathrm{W} 35$, this is about $3.84 \%$ whereas the theoretical ideal benefit is $9.7 \%$. The same counts for the living condition of $\mathrm{W} 10 / \mathrm{W} 45$ where the actual profit is $2.07 \%$ while theoretical profit in ideal conditions is $15.9 \%$.

Per calculations of the living condition of W10/W45, it can be stated that the simultaneous production of heat for DHW with a higher COP is more than the demand of $4000 \mathrm{kWh}$. For that reason, no extra DHW needs to be produced like in living condition of W10/W35.

The difference between the profit after $1 \mathrm{hr}$ and the profit after $1 \mathrm{yr}$ for the living condition of W10/W45 is very small. This is because the COPs of HGW technology for production of SH and production of DHW are close to each other.

The extra cost of installation of the HGW technology can be paid back after less than nine and a half years, which is longer than the theoretical five and a half years. The payback time in reality is thus longer than the payback time in ideal conditions because of the ratio of the COPs between a regular HP system and an HP system with HGW technology. In this case, the amount of DHW that is not produced simultaneously will be produced on a COP (DHW) that is only $30 \%$ lower. Theoretically, this COP was $50 \%$ lower. On the other hand, the living condition of W10/W45 using HGW technology will gain a profit of only $2.07 \%$, and the payback time for installing the HGW technology is approximately 14 yrs.

7.3.2 Small Hotel Case. Like it was clear in the analysis of an average family house case, the actual COP values in this case would be lower than the theoretical ones; thus, the annual electrical consumption would be higher in reality.

As mentioned in the theoretical analysis of small hotels, the contribution of HGW technology is less interesting in this type of building. The reason for that is the higher demand of DHW production and the fact that there will be more DHW production with a lower COP. Yet, the difference between these COPs is very small, so there would be still some profit to make.

For a small hotel, the payback time is equal to the one for an average family house because of the same COPs. As the DHW demand is greater, the annual electrical consumption becomes a lot higher.

7.4 Comparison to Another SH System: Condensing Boiler. An efficient condensing combi-boiler, namely, a Viessman Vitodens 333-F [10], is selected for this comparison and it is ideal for low-temperature systems such as floor heating. The heating system contains a boiler tank of $100 \mathrm{~L}$ capacity for DHW production just like the HP system of the test setup in GeoTherma.

For an average family house in the living condition of W10/ W35, the HP system with HGW technology has a supplementary cost of $€ 2112$ per values in Refs. [11-14]. The payback time is 3.5 years by means of an energy saving of approximately $600 € /$ years. Although this is a reasonable payback time for an HP versus a condensation boiler, it has to be taken into account that the calculation of the payback time only includes the purchase cost of the machines and not the installation costs. This cost for an HP system is much higher than the installation cost of a condensation boiler, e.g., it costs almost the same price as the purchase price of the HP. This higher amount is caused by the ground loop heat exchangers that must be vertically or horizontally placed in the ground. Thus, the payback time is approximately twice as long. However, when examining the energy cost per year, it should be noted that a saving of around $€ 500$ can be made per year when using an HP system which makes it an attractive investment.

\section{Conclusions}

Experimental and theoretical analyses of a ground sourced HP system with HGW technology used for the simultaneously production of SH and DHW were presented. For a living situation condition of $\mathrm{W} 10 / \mathrm{W} 35$ at a temperature of $35^{\circ} \mathrm{C}$, a profit of $11.02 \%$ would be obtained in theory which is even higher than the $10 \%$ claimed by the manufacturer. On the other hand, the theoretical profit for living condition of W10/W45 is $17.91 \%$ because of the selection of perfect isentropic efficiency. This, however, is not possible in reality. For that reason, the living condition of W10/ W35 shows more realistic results after these calculations. But it must be taken into account that these calculations were done for ideal conditions. In reality, the profit will be smaller.

A comparison of HGW technology use in a house versus a small hotel was made, and these cases were then compared to standard HP system. Results showed that in order to provide SH and DHW for the living condition of W10/W35 in an average family house, the savings may go up to approximately $10 \%$ on an annual basis. On the other hand, this living condition in a small hotel with higher DHW demand only gets $4.36 \%$ savings per year. As for the living condition of W10/W45, there is less profit.

In conclusion, the results of this study have proved that the $10 \%$ efficiency profit claimed by the manufacturer is not achieved by using an HP system with HGW technology. However, during the actual measurements, a profit of approximately 5\% was noticed for a living condition of W10/W35. This result is higher than the standard test conditions of B0/W35. This is also the reason why the calculated COP value of 4.6 is higher than the COP of 4.3 reported on the technical datasheet of the HP system. For the living condition of W10/W45, an HP with HGW technology is less meaningful because of the lower profit of $3.6 \%$. However, this system can produce more DHW simultaneously because of the higher distribution of the total heat capacity transferred by the desuperheater.

It was found that when HGW technology is installed in an average family house, there could be a saving of about $€ 42.16$ per year. Comparing to the purchase price of the HP, this means that the payback would be less than nine and a half years. An HP system with HGW technology is an attractive investment, because of its energy efficient operation in comparison to other SH systems. When purchasing an HP system with HGW technology versus a condensing boiler, the additional cost of the device would be gained back in less than 4 yrs because of an annual saving of about $€ 600$. However, due to the high purchase price of the HP installation on top of the purchase price of the HP system, end users tend to often choose other type of heating systems.

$$
\begin{aligned}
& \text { Nomenclature } \\
& \mathrm{COP}=\text { coefficient of performance } \\
& \mathrm{DHW}=\text { domestic hot water } \\
& \dot{E}=\text { rate of energy }(\mathrm{kW}) \\
& \mathrm{GHP}=\text { geothermal heat pump } \\
& h=\text { enthalpy }(\mathrm{kJ} / \mathrm{kg}) \\
& \mathrm{HGW}=\text { hot gas water } \\
& \mathrm{HP}=\text { heat pump } \\
& \mathrm{Liq}=\text { liquid } \\
& \dot{m}=\text { mass flow }(\mathrm{kg} / \mathrm{s}) \\
& P=\text { pressure }(\mathrm{kPa}) \\
& Q=\text { heat }(\mathrm{kWh}) \\
& \dot{Q}=\text { heat transfer rate }(\mathrm{kW})
\end{aligned}
$$




$$
\begin{aligned}
\stackrel{s}{S} & =\text { entropy }(\mathrm{kJ} / \mathrm{kg} \mathrm{K}) \\
\dot{S} & =\text { entropy rate }(\mathrm{kW} / \mathrm{K}) \\
\mathrm{Sat} & =\text { saturated } \\
\mathrm{SH} & =\text { space heating } \\
T & =\text { temperature }(\mathrm{kJ} / \mathrm{kg} \mathrm{K}) \\
\mathrm{Vap} & =\text { vapor } \\
\text { VAT } & =\text { value added tax } \\
W & =\text { work }(\mathrm{kWh})
\end{aligned}
$$

\section{Subscripts}

$$
\begin{aligned}
C & =\text { condenser } \\
\text { Comp } & =\text { compressor } \\
D & =\text { desuperheater } \\
\text { Dest } & =\text { destroyed } \\
E & =\text { evaporator } \\
\mathrm{Ev} & =\text { expansion valve } \\
\mathrm{Gen} & =\text { generated } \\
H & =\text { heat output } \\
\mathrm{in} & =\text { input } \\
L & =\text { source input } \\
\mathrm{Max} & =\text { maximum } \\
\mathrm{Out} & =\text { output } \\
R & =\text { refrigerant } \\
S & =\text { isentropic } \\
T & =\text { total } \\
W & =\text { water } \\
0 & =\text { dead state }
\end{aligned}
$$

\section{Greek Symbols}

$\dot{W}=\operatorname{power}(\mathrm{kW})$

$\dot{X}=$ rate of exergy $(\mathrm{kW})$

$$
\begin{aligned}
& \eta=\text { efficiency } \\
& \rho=\text { density }
\end{aligned}
$$

\section{References}

[1] Song, Z. P., 2008, "A Theoretical Study on Decentralized Space Heating System," ASME J. Energy Resour. Technol., 130(3), p. 032401.

[2] Wong, K. V., and Tan, N., 2015, "Feasibility of Using More Geothermal Energy to Generate Electricity," ASME J. Energy Resour. Technol., 137(4), p. 041201.

[3] Lund, J. W., Freeston, D. H., and Boyd, T. L., 2011, "Direct Utilization of Geothermal Energy 2010 Worldwide Review," Geothermics, 40(3), pp. 159-180.

[4] Gunes, M. B., and Ellis, M. W., 2003, "Evaluation of Energy, Environmental, and Economic Characteristics of Fuel Cell Combined Heat and Power Systems for Residential Applications,” ASME J. Energy Resour. Technol., 125(3), pp. 208-220.

[5] Somasundaram, S., Winiarski, D. W., and Belzer, D. B., 2002, "Screening Analysis for EPACT-Covered Commercial HVAC and Water Heating Equipment," ASME J. Energy Resour. Technol., 124(2), pp. 116-124.

[6] Fernández-Seara, J., Pereiro, A., Bastos, S., and Dopazo, J. A., 2012 "Experimental Evaluation of a Geothermal Heat Pump for Space Heating and Domestic Hot Water Simultaneous Production," Renewable Energy, 48, pp. 482-488.

[7] Blanco, D. L., Nagano, K., and Morimoto, M., 2012, "Steady State Vapor Compression Refrigeration Cycle Simulation for a Monovalent Inverter-Driven Water-to-Water Heat Pump With a Desuperheater for Low Energy Houses Desuperheater," Int. J. Refrig., 35(7), pp. 1833-1847.

[8] European Committee for Standardization (CEN) Technical Committee, 113 2008, "Luchtbehandelingsapparatuur, koeleenheden met vloeistof en warmtepompen met elektrisch aangedreven compressoren voor ruimteverwarming en koeling -Deel 2: Beproevingsomstandigheden," 2nd ed., Geregistreerde Belgische norm, Brussels, Belgium CEN Standard No. NBN EN 14511-2.

[9] Eurostat, 2015, "Electricity and Natural Gas Price Statistics," European Commission, Brussels, Belgium.

[10] Viessmann, "Condensation Boilers," Viessmann Belgium BVBA, Nossegem, Belgium.

[11] WTCB, 2016, "Een TV Over Condensatieketels," Wetenschappelijk en Technisch Centrum voor het Bouwbedrijf, Brussels, Belgium.

[12] International Energy Agency, 2012, "Natural Gas Information," Imprimerie Centrale, Luxembourg.

[13] Vlaamse Overheid, 2006, "Ketelrendementen," http://www2.vlaanderen.be/economie/energiesparen/epb/doc/module43bijlage.pdf

[14] VREG, 2016, “Aardgas," Vlaamse Reguleringsinstantie voor de Elektriciteits- en Gasmarkt, Brussels, Belgium, http://www.vreg.be/nl/aardgas-omrekening-vanm3-naar-kwh 